\title{
ANALISIS INOVASI PELAYANAN PUBLIK BERBASIS APLIKASI TANGERANG LIVE DI KOTA TANGERANG
}

\section{Wahyu Hidayat}

wahyujulio99@gmail.com

Dosen STISIPOL P12

\begin{abstract}
ABSTRAK
Kondisi pelayanan publik di Indonesia masih sangat rendah. Begitu juga dengan kondisi pelayanan publik khususnya di Kota Tangerang masih belum optimal beberapa permasalahan yang muncul seperti, Sistem dan prosedur pelayanan yang berbelit-belit, dan sumber daya manusia yang lamban dalam memberikan pelayanan, mahal, tertutup, dan diskriminatif. Dengan permasalahan seperti itu mendorong Pemerintah Kota Tangerang untuk meningkatkan kualitas pelayanan publik dengan sebuah inovasi layanan Aplikasi Tangerang Live. Penelitian ini berjudul Analisis Inovasi Pelayanan Publik Berbasis Aplikasi Tangerang Live. Penelitian ini bertujuan menganalisis pelaksanaan dan faktor pendukung serta penghambat pelaksanaan Inovasi Pelayanan Publik Berbasis Aplikasi Tangerang Live. Penelitian ini menggunakan Teori Roger, dengan 5 atribut inovasi yaitu: Relative Advantage (keuntungan relative), Compability (kesesuaian), Complexity (kerumitan), Triability (kemungkinan dicoba) dan Observability (kemudahan diamati). Penelitian menggunakan Pendekatan Kualitatif dan Metode Deskriptif. Penelitian ini dilaksanakan di Dinas Komunikasi dan Informatika Kota Tangerang. Waktu penelitian sejak Maret sampai November 2017. Teknik pengumpulan data yaitu Observasi, Wawancara dan Dokumentasi. Teknik Pemilihan Informan Menggunakan Purposive. Uji keabsahan data menurut Moleong ada empat keabsahan data yaitu kepercayaan, keteralihan, kebergantungan dan kepastian. Langkah yang digunakan dengan Triangulasi. Hasil penelitian pelaksanaan Inovasi Pelayanan Publik Kota Tangerang sudah berjalan dengan baik kerena telah mejawab kebutuhan masyarakat dan banyak memberikan keuntungan baik dari segi waktu, kepraktisan dan kemudahan dalam mendapatkan pelayanan. Meskipun masih perlu adanya sosialisasi secara persuasive guna memastikan bahwa masyarakat benar-benar dapat menggunakan menggunakan pelayanan berbasis teknologi Aplikasi Tangerang Live.
\end{abstract}

Kata kunci: Inovasi Pelayanan, Aplikasi Tangerang Live

\begin{abstract}
The condition of public services in Indonesia is still very low. Likewise, the condition of public services, especially in Tangerang City, is still not optimal, several problems that arise such as, complicated service systems and procedures, and slow human resources in providing services, expensive, closed, and discriminatory. With such problems, it encourages the Tangerang City Government to improve the quality of public services with an innovative Tangerang Live Application service. This research is entitled Analysis of Public Service Innovation Based on Tangerang Live Application. This study aims to analyze the implementation and the supporting and inhibiting factors for implementing the Tangerang Live Application-Based Public Service Innovation. This study uses Roger's Theory, with 5 innovation attributes, namely: Relative Advantage (relative advantage), Compability (suitability), Complexity (complexity), Triability (possibility to try) and Observability (easy to observe). The research uses a qualitative approach and descriptive method. This research was conducted at the Department of Communication and Information Tangerang City. The research time was from March to November 2017. The data collection techniques were Observation, Interview and Documentation. Informant Selection Technique Using Purposive. According to Moleong, there are four data validity tests, namely trust, transferability, dependence and certainty. Steps used with Triangulation. The results of the research on the implementation of the Tangerang City Public Service Innovation have gone well because it has answered the needs of the community and has provided many benefits both in terms of time, practicality and ease of getting services. Although there is still a need for persuasive socialization to ensure that people can actually use technology-based services using the Tangerang Live Application.
\end{abstract}

Keywords: Service Innovation, Tangerang Live Application 


\section{PENDAHULUAN}

Pelayanan Publik merupakan pemberian pelayanan (melayani) yang dilaksanakan oleh penyelenggara pelayanan publik sebagai upaya untuk pemenuhan kebutuhan dan keperluan penerima pelayanan atau masyarakat maupun pelaksana ketentuan peraturan perundang-undangan yang mempunyai kepentingan pada organisasi tersebut sesuai dengan aturan pokok dan tata cara yang telah di tetapkan. (Ramli: 2013). Hal ini sesuai dengan yang disebutkan dalam Undang-Undang No 25 Tahun 2009 tentang pelayanan publik, dimana dalam melaksanakan pelayanan publik pemerintah membentuk organisasi penyelenggara. Penyelenggara adalah setiap institusi penyelenggara negara, korporasi,lembaga independen yang dibentuk berdasarkan undang-undang untuk kegiatan pelayanan publik, dan badan hukum lain yang dibentuk semata-mata untuk kegiatan pelayanan publik. Penyelenggara dan seluruh bagian organisasi penyelenggara bertanggung jawab atas ketidakmampuan, pelanggaran, dan kegagalan penyelenggaraan pelayanan.

Pelayanan yang berkualitas dan bermutu tinggi menjadi perhatian utama dari organisasi publik. Keterbukaan informasi, jika dikaitkan dengan aktivitas pelayanan, ikut mendorong masyarakat kian sadar tentang hak dan kewajibannya. Oleh karena itu, harapan untuk bisa mendapatkan pelayanan yang terbaik tersebut, ini juga mulai digantungkan kepada organisasi pemerintahan (Agus, 2006) terselenggaranya pelayanan publik yang baik, tergantung dari kondisi birokrasi di suatu negara. Kondisi birokrasi memberikan iklim tersendiri bagi terselenggaranya pelayanan publik yang optimal. Pelayanan publik yang optimal belum dapat direalisasikan di Indonesia. Kondisi pelayanan publik di Indonesia masih sangat rendah. Dalam sektor publik, inovasi sangat diperlukan dalam pengembangan suatu pelayanan publik. Inovasi hadir sebagai sebuah produk yang baru dan sifatnya menggantikan cara yang lama. Ini artinya bahwa setiap pelayanan publik, secara isi pada prinsipnya harus memuat sebuah inovasi baru.

Direktur Eksekutif Institute Democracy and Education (IDE) Gugun Gumilar dalam Cidahu News, Jumat (01/01/2016) yang menilai bahwa secara umum, citra layanan publik di Indonesia, dari zaman dahulu hingga kini, lebih dominan sisi negatifnya dari pada sisi positifnya. Selain prosedur yang bertele-tele, petugas yang kurang ramah, mahal senyum dan terkadang tidak profesional, hingga STISIPOL Pahlawan 12 Sungailiat Bangka ujung-ujungnya duit sudah tidak asing pula kalau layanan publik di Indonesia dicitrakan sebagai salah satu sumber korupsi. Permintaan uang (pungutan liar) sudah menjadi masalah yang biasa kita jumpai. Baik Kuantitas (Akses), maupun Kualitas pelayanan publik di Indonesia masih buruk (belum memadai) baik dilihat dari kebutuhan masyarakat maupun dari standar yang ada. Jika tidak ada langkah perbaikan signifikan, target negara ini untuk menggapai tujuh besar ekonomi dunia akan sirna begitu saja.(Bambang, 2016)

Penerapan ide-ide baru dan gagasan cemerlang dalam penyelenggaraan pelayanan publik dimaksudkan untuk menciptakan pelayanan publik yang lebih baik, lebih bermakna, memiliki nilai tambah baik sebagai individu penyelenggara pelayanan dan dalam tataran manajemen organisasi yang lebih luas. Inovasi dalam penyelenggaran pelayanan publik yang bersumber dari motivasi diri dan organisasi dimaksudkan untuk pemenuhan kebutuhan publik juga dimaksudkan untuk menjaga eksistensi dan menghadapi dinamika lingkungan internal dan eksternal. Pengelolaan pelayanan publik di era otonomi daerah menjadi variabel penting yang akan mempengaruhi proses menjadi daerah otonom yang berhasil. Salah kelola akan mengurangi hak publik sebagai pihak yang seharusnya menerima manfaat dari kehadiran Kota Tangerang. Oleh karena itu, peningkatan fungsi pelayanan terhadap masyarakat harus menjadi prioritas utama.

Sejauh ini, kualitas pelayanan publik Kota Tangerang secara umum sudah bagus terutama dalam pelayanan administrasi kependudukan, sehingga jika dinilai dengan angka sudah mencapai 70 mendekati 80 . (Bambang Poerwanto Sumo, dalam H. Felix Mulyawan, 2017). Namun ada beberapa pelayanan yang harus lebih ditingkatkan, seperti pelayanan perizinan dan penanaman modal, pendidikan, pertanian dan sosial khususnya loket-loket pelayanan prosedurnya dan juga biayanya yang tidak jelas.

Kualitas pelayanan publik berperan penting dalam mewujudkan kesejahteraan masyarakat. Untuk itu, meskipun secara umum pelayanan publik di Kota Tangerang sudah baik, namun masih terdapat permasalahan-permasalahan yang sering dikeluhkan oleh masyarakat seperti; Pelayanan yang lamban, prosedur yang berbelit-belit, serta biaya yang tidak jelas. Oleh karena itu Pemkot Tangerang juga harus berinovasi untuk memberikan pelayanan yang prima kepada masyarakat. (M. Rangkuti, 2017). Sehingga masyarakat di Kota Tangerang bisa merasakan manfaat apa yang telah dilakukan oleh pemerintah daerahnya, tuntutan akan adanya pelayanan publik yang berkualitas inilah yang telah mendorong Pemerintah 
Kota (Pemkot) Tangerang untuk melakukan inovasi dalam reformasi birokrasi.

Dengan demikian Pemerintah Kota Tangerang melalui Dinas Komunikasi dan Informatika, membuat sebuah inovasi dengan memanfaatkan kecanggihan teknologi diera modern. Bentuk inovasi pelayanan yang dimaksud yaitu sebuah pelayanan online yang berbasis aplikasi yang disebut Aplikasi Tangerang Live. Penggunaan layanan ini tidak dipungut biaya, hanya saja masyrakat perlu mengunduh atau mendowload aplikasi di smartphone atau Hp yang bebasis android. Dengan sekali unduh masyarakat sudah bisa menikmati layanan Pemerintah Kota Tangerang melalui Aplikasi Tangerang Live tersebut. Dengan adanya Aplikasi Tangerang Live ini berbagai aktifitas pegawai hingga masyarakat akan terpantau secara langsung melalui layar kaca besar dan telepon genggam Walikota dari aplikasi yang tersedia. (http://tangerangkota.go.id/peresmian-tangeranglive-room-oleh-walikota-tangerang-h-arief-rwismanyah. akses 14 September 2017 ).

Bertolak dari uraian diatas, hal ini menarik untuk diteliti secara mendalam mengenai inovasi yang dilakukan oleh Pemerintahan Kota Tangerang dalam rangka memperbaiki kualitas pelayanan publik melalui Aplikasi Tangerang Live. dengan demikian timbul rumusan masalah sebagai berikut;

Tujuan penelitian ini untuk menganalisis inovasi yang dilakukan oleh KotaTangerang melalui Aplikasi Tangerang Live dalam rangka memperbaiki kualitas pelayanan publik. Dan untuk menganalisis faktor pendukung dan penghambat Inovasi Pelayanan Publik melalui Aplikasi Tangerang Live. Teori Inovasi

Inovasi menurut Evert M. Rogers (Suwarno, 2008:9) adalah sebagai suatu ide, gagasan, praktek atau objek/benda yang disadari dan diterima sebagai suatu hal yang baru oleh seseorang atau kelompok untuk diadopsi. Menurut Rogers dalam Yogi Suwarno (2008: $17-18)$, ada 5 atribut inovasi yaitu :

Relative Advantage atau keuntungan relative

Sebuah inovasi harus mempunyai keuntungan dan nilai lebih dibandingkan dengan inovasi sebelumnya. Suatu inovasi dapat dilhat keuntungan relatifnya bagi para penggunanya. Calon pengguna akan menilai sesuatu hal yang baru berdasarkan keuntungan relatif dari hal tersebut menurut prsepsinya. Suatu inovasi dipersepsikan memiliki keuntungan relatif tinggi jika inovasi tersebut dinilai oleh pengguna sebagai inovasi yang dapat meningkatkan keuntungan secara ekonomis. Keuntungan relatif suatu inovasi dapat diketahui setelah inovasi tersebut dibandingkan dengan inovasi sebelumnya.

Compability atau kesesuaian. Mempunyai sifat compatibel atau kesesuaian dengan inovasi yang diganti. Hal ini dimaksudkan agar inovasi yang lama tidak serta merta dibuang begitu saja selain karena alasan faktor biaya yang sedikit namun juga inovasi yang lama menjadi bagian dari proses transisi ke inovasi baru. Calon pengguna dapat menilai sesutu inovasi berdasarkan kesesuaian antara inovasi tersebut dengan ide dan cara yang telah ada sebelumnya, kesesuaian dengan nilai-nilai atau norma yang berlaku, dan kesesuaian dengan berbagai latar belakang lainya.

Complexity atau kerumitan. Dengan sifatnya yang baru maka inovasi mempunyai tingkat kerumitan yang lebih tinggi dibandingkan dengan inovasi sebelumnya. Calon pengguna akan menilai apakah suatu inovasi itu dianggap rumit atau simple dalam hal penggunaanya. Semakin rumit pengguna suatu inovasi menurut pandangan calon pengguna maka akan semakin rendah tingkat penggunaanya begitupun sebaliknya semakin simple penggunaan suatu inovasi menurut pandangan calon pengguna maka akan semakin tinggi tingkat penggunaanya.

Triability atau kemungkinan dicoba. Inovasi hanya bisa diterima apabila telah teruji dan terbukti mempunyai keuntungan atau nilai lebih dibandingkan dengan inovasi yang lama. Suatu inovasi akan dinilai oleh calon penggunanya dalam hal kemungkinannya untuk dicoba. Apabila suatu inovasi memiliki sifat mudah dicoba maka tingkat potensi untuk menyebar luas dalam masyarakat.

Observability atau kemudahan diamati. Sebuah inovasi harus dapat diamati dari segi bagaimana ia bekerja dan menghasilkan sesuatu yang lebih baik.

Sementara menurut Wijayanti (2008: 42) dalam Weny dan Retnowati WD Tuti berpendapat bahwa inovasi di sektor publik lebih menekankan aspek "Perbaikan" yang dihasilkan dari kegiatan inovasi ini, yang pemerintah lakukan mampu memberikan layanan publik secara lebih efektif, efisien dan berkualitas, murah dan terjangkau. Inovasi menurut Edy Sutrisno, 2010: 105, dalam Weny dan Retnowati WD Tuti bahwa inovasi adalah pengenalan cara-cara baru yang lebih baik melakukan pekerjaan di tempat kerja. Inovasi tidak menyiratkan pembaruan syarat absolut dan perubahan dapat terjadi dilihat sebagai inovasi jika perubahan tersebut dianggap baru untuk grup atau organisasi yang diperkenalkan.

Berdasarkan pandangan diatas bahwa inovasi berarti pemanfaatan suatu peluang yang dirubah menjadi ide-ide, hal-hal, dan penemuan baru dengan melalui proses kreatifitas yang tinggi. Penemuan ide 
ANALISI INOVASI PELAYANAN PUBLIK BERBASIS APLIKASI TANGERANG LIVE.DI KOTA TANGERANG

baru ini disesuaikan dengan ide-ide yang sudah ada

sebelumnya. Dalam hal ini sebuah inovasi bisa

dikatakan juga sebuah pengembangan atau pembaharuan dari nilai-nilai yang sudah ada sebelumnya.

Pelayanan publik

Menurut Pasolong (2010:128), pelayanan pada dasarnya didefinisikan sebagai aktifitas seseorang, sekelompok dan atau organisasi baik secara langsung maupun tidak langsung untuk memenuhi kebutuhan. Jadi dapat dikatakan bahwa dalam pelayanan terdapat dua aspek yaitu seseorang atau organisasi dan pemenuhan kebutuhan.

Menurut Widodo Joko, (2001), pelayanan publik adalah pemberian layanan (melayani) keperluan orang atau masyarakat yang mempunyai kepentingan pada organisasi tersebut sesuai dengan tata cara yang telah ditetapkan. (Diah, 2014). Pelayanan publik menurut Agus, (2005: 141) dalam (Weny dan Retnowati, 2017) bahwa pelayanan publik didefinisikan sebagai serangkaian aktivitas yang dilakukan oleh birokrasi publik untuk memenuhi kebutuhan warga pengguna.

Menurut Sinambela (2006:5) dalam (Weny dan Retnowati, 2017), bahwa pelayanan publik adalah pemenuhan keinginan dan kebutuhan masyarakat oleh penyelenggara negara. Selanjutnya menurut Setijaningrun (2009:1) pelayanan publik (public service) merupakan salah satu perwujudan dari fungsi aparatur negara sebagai abdi masyarakat disamping sebagai abdi Negara. Sedangkan Agung dalam (Masdar dkk, 2009:42) mengatakan bahwa pelayanan publik adalah pemberian pelayanan (melayani) keperluan orang lain atau masyarakat yang mempunyai kepentingan pada organisasi itu sesuai dengan aturan dan tata cara yang telah ditetapkan.

Berdasarkan padangan diatas bahwa pelayanan publik berarti suatu aktivitas atau kegiatan melayani semua kebutahan dan kepentingan masyarakat sesuai dengan aturan yang berlaku. Dalam hal ini pihak pemberi layanan harus memberikan pelayanan yang baik untuk menciptakan kepuasaan bagi warga sebagai pengguna layanan sesuai dengan aturan dan prosedur yang ditetapkan.

\section{Sistem Informasi}

Sistem informasi merupakan hal yang sangat penting dalam manajemen di dalam pengambilan keputusan. Sistem ini memanfaatkan perangkat keras dan perangkat lunak komputer, prosedur manual, model manjemen dan basis data. Adapun pengertian sistem informasi menurut para ahli sebagai berikut: Menurut Prahasta (2001:42), "sistem informasi adalah entity (kesatuan) formal yang terdiri dari berbagai sumber daya maupun logika."Menurut James B Bower dalam Wahyono (2004:17), "sistem informasia adalah suatu cara tertentu untuk menyediakan informasi yang dibutuhkan oleh organisasi untuk beroperasi dengan cara yang sukses dan untuk organisasi bisnis dengan cara yang menguntungkan." Menurut Jugi (2000: 35) menyatakan bahwa sistem informasiadalah suatu kegiatan dari prosedur prosedur yang diorganisasikan, bilamana dieksekusi akan menyediakan informasi untuk mendukung pengambilan keputusan dan pengendalian di dalam organisasi.

Dari pandangan di atas berarti sistem inovasi suatu cara yang menyediakan informasi untuk mendukung pengambilan keputusan dan pengendalian didalam organisasi dengan cara menguntungkan. Dalam artian cara yang digunakan dalam menyampaikan informasi menggunakan perangkat keras dan perangkat lunak seperti komputer yang berbasis data.

Dalam menganalisis Pelaksanaan Inovasi Aplikasi Tangrang Live tersebut digunakan tori yang dikemukakan oleh Roger dalam Yogi Suwarno. Menurut Rogers dalam Yogi (2008: 17 - 18), ada 5 Indikator dalam inovasi yaitu :

Relative Advantage atau keuntungan relative

Sebuah inovasi harus mempunyai keuntungan dan nilai lebih dibandingkan dengan inovasi sebelumnya.

\section{Compability atau kesesuaian}

Mempunyai sifat Compatibel atau kesesuaian dengan inovasi yang diganti. Hal ini dimaksudkan agar inovasi yang lama tidak serta-merta dibuang begitu saja selain karena alasan faktor biaya yang sedikit namun juga inovasi yang lama menjadi bagian dari proses transisi ke inovasi baru.

Complexity atau kerumitan

Dengan sifatnya yang baru maka inovasi mempunyai tingkat kerumitan yang lebih tinggi dibandingkan dengan inovasi sebelumnya.

Triability atau kemungkinan dicoba

Inovasi hanya bisa diterima apabila telah teruji dan terbukti mempunyai keuntungan atau nilai lebih dibandingkan dengan inovasi yang lama.

Observability atau kemudahan diamati

Sebuah inovasi harus dapat diamati dari segi bagaimana ia bekerja dan menghasilkan sesuatu yang lebih baik.

\section{METODE PENELITIAN}

Dalam penelitian ini menggunakan pendekatan kualitatif deskriptif yaitu untuk mengetahui atau menggambarkan kenyataan dari kejadian yang diteliti. Kecenderungan untuk menggunakan metode penelitian ini karena dianggap sangat relevan dengan materi penulisan Tesis. 
Sehingga memudahkan untuk mendapatkan data yang objektif dalam rangka mengetahui dan memahami kejadian yang diteliti.

Teknik Pengumpulan Data

Teknik pengumpulan data yang digunakan dalam penelitian ini adalah :

Observasi

Observasi ini digunakan untuk penelitian yang telah direncanakan secara sistematik terkait temuan pada objek penelitian. Dalam penelitian ini ada beberapa yang dapat diobservasi terkait inovasi pelayanan publik yang berbasis Aplikasi Tangerang Live. Adapun yang di observassi yaitu Gedung Pemerintahan Kota Tangerang, Kantor Diskominfo Kota Tangerang, dan Ruang Command Center atu Live Room.

Wawancara

menggunakan metode indepth interview, dimana peneliti dan informan berhadapan langsung untuk mendapatkan informasi secara lisan dengan tujuan data yang dapat menjelaskan permasalahan penelitian.

Dokumentasi

Dalam penelitian ini terkait Aplikasi Tangerang Live di Kota Tangerang, dokumendokumen yang dianggap menunjang terhadap permasalahan yang akan diteliti seperti: Peraturan Walikota Tangerang No 3 Tahun 2016, tentang pembentukan organisasi dan tata kerja unit pelaksana teknis command center pada dinas komunikasi dan informatika, UU No. 25 Tahun 2009 tentang pelayanan publik dan SOP Tentang Pelayanan publik Aplikasi Tangerang Live. Selain itu dokumentasi diperoleh dari Majalah Benteng Surat Kabar Warta Kota, Tangerang News, Liputan6.com, Antara News yang memuat informasi tentang Aplikasi Tangerang Live.

Teknik Pemilihan Informan

Penentuan informan dalam penelitian ini melalui teknik purposive. Dalam penelitian ini informan diambil berdasarkan pertimbangan sesuai dengan jabatan yang diembannya yang memiliki keterkaitan dengan objek penelitian yaitu Aplikasi Tangerang Live. Adapun informan yang dipilih dalam teknik ini adalah 3 orang staf pegawai Diskominfo Kota Tangerang sesuai dengan jabatan yang berkaitan dengan pelaksanaan Aplikasi Tangerang Live yaitu Sekertaris Dikominfo Kota Tangerang, Kepala Seksi Pengembangan dan Kemitraan Dinas Komunikasi dan Informatika Kota Tangerang, KA UPT Pengelolaan Ruang Kendali Kota/ KA TU UPT dan 1 Operator.

Sedangkan untuk pemilihan inforaman dari pengguna Aplikasi Tangerang Live dalam hal ini adalah warga yang benar-benar telah menggunakan Aplikasi Tangerang Live. Dalam hal ini digunakan teknik accidental sebanyak 7 orang warga yang dipilih sesuai dengan kretaria yaitu warga yang benar-benar telah memiliki Aplikasi Tangerang Live dan telah menggunakanya.

\section{HASIL PENELITIAN DAN PEMBAHASAN}

Selain sifatnya yang baru, suatu inovasi dapat diterima oleh adopter apabila suatu inovasi dapat memberikan keuntungan dan nilai lebih kepada calon adopter. Untuk lebih jelas dan terperinci akan diuraikan melalui atribut Inovasi yang digunakan untuk menganalisis pelaksanaan inovasi pelayanan publik yang berbasis Aplikasi Tangerang Live sebagai berikut;

Relative Advantage (Keuntungan Relatif). Keuntungan bagi Pemerintah Dengan adanya Aplikasi Tangerang Live dapat memahami kebutuhan dan aspirasi msyarakat karena pelaksanaan pelayanan publik Aplikasi Tangerang Live didasarkan pada kebutuhan nyata dan aspirasi masyarakat. Sedangankan bagi masyarakat : Memberikan jaminan bahwa pelayanan publik menjadi lebih responsif, artinya penyelenggaraan pelayanan publik didasarkan pada kebutuhan nyata masyarakat pengguna layanan sehingga terdapat kesesuaian antara pelayanan yang diberikan dengan kebutuhan masyarakat. Disamping itu memberikan jaminan transparansi bagi masyarakat, artinya masyarakat bisa mengetahui denganmudah aspek-aspek pelayanan baik mengenai jenis, prosedur, waktu, biaya dan cara pelayanannya. Dan lebih akuntabel artinya pelayanan publik yang diberikan dapat dipertanggungiawabkan kepada masyarakat selaku pengguna layanan. Yang kedua, Memberi kemudahan kepada masyarakat untuk mengakses informasi pelayanan dan sekaligus melakukan kontrol terhadap penyelenggaraan pelayanan, karena masyarakat dilibatkan secara langsung dalam proses pelayanan.

Compatibility (kesesuaian) Aplikasi Tangerang Live mempunyai kesesuaian dengan Aplikasi sebelumnya. Aplikasi sebelumnya tidak serta-merta dibuang tatepi menjadi bagian dari Aplikasi Tangerang Live. Aplikasi Tangerang Live juga mempunyai kesesuai dengan sarana dan prasarana yang dibutuhkan yaitu, perangkat tekhnologi seperti; server, jaringan internet dan ruang kendali atau disebut dengan command center.

Complexity (kerumitan) dalam pelaksanaan Aplikasi Tangerang Live kerumitan yang dimiliki tidak lah penting karena prosedur penggunaannya tentu sudah disosialisasikan baik melalui media cetak, elektronik maupun tatap muka. Kerumitan yang dimiliki Aplikasi Tangerang Live disebabkan oleh 
kecanggihannya dibandingkan aplikasi sebelumnya yang masih sederhana.

Triability (kemungkinan dicoba) dalam pelaksanaan Aplikasi Tangerang Live telah melewati fase uji coba selama lebih kurang tiga bulan. Melalui tahapan uji coba dapat diketahui sejauh mana inovasi ini dapat menjawab kebutuhan dan tuntutan dari masyarakat. Dalam pelaksanaan inovasi ini Pemerintahan Kota terus mengupayakan penyempurnaan sistem aplikasi yang awalnya menggunakan versi 3.0.0 sampai saat ini sudah menggunakan versi 3.7.0. hal ini terus dikembangkan sesuai denga kebutuhan masyarakat.

Observability (Kemudahan diamati) setelah pemerintah mengupayakan sosialisasi tentang prosedur dan cara penggunaan inovasi Layanan Aplikasi Tangerang Live, masyarakat dapat mengamati kemudahan dan keunggulan yang dimilki layanan Aplikasi Tangerang Live. Sehingga masyarakat dapat memutuskan untuk menggunakan Aplikasi Tangerang Live. Dalam pelaksanaan Aplikasi Tangerang Live bukan hanya dipanatau dan diamati tetapi masyarakat dapat memberikan kritik dan saran serta kontribusi dalam membangun dan mengembangkan inovasi layanan Aplikasi Tangerang Live.

Berdasarkan 5 atribut inovasi diatas dapat diketahui hasil penelitian terkait pelaksanaan Inovasi Aplikasi Tangerang Live sudah berjalan dengan baik karena sudah sesuai dengan 5 atribut inovasi yang diungkapkan oleh Roger. Dengan adanya Aplikasi Tangerang Live dapat memberikan keuntungan kepada masyarakat dalam mendapatkan pelayanan dari Pemerintah. Selain itu Aplikasi Tangerang Live mempnyai kesesuain dengan Aplikasi-aplikasi sebelumnya. Artinya aplikasi sebelimnya tetap bagian dari Aplikasi Tangerang Live.

\section{KESIMPULAN}

\section{Simpulan}

Dari hasil penelitian diatas dapat disimpulkan bahwa Inovasi Layanan publik yang berbasis Aplikasi Tangerag Live sudah berjalan cukup baik dan berkualitas karena mampu menjawab kebutuhan masyarakat sehingga mendapatkan respon positif dari masyarakat. Keuntungan bagi Pemerintah Kota Tangerang dengan adanya Aplikasi Tangerang Live dapat memahami kebutuhan dan aspirasi msyarakat karena pelaksanaan pelayanan publik Aplikasi Tangerang Live didasarkan pada kebutuhan nyata dan aspirasi masyarakat. Selain itu dengan adanya Aplikasi Tangeraang Live dapat memberikan kemudahan kepada Pemerintah Kota Tangerang dalam mengontrol kinerja para pegawai baik yang bertugas dilapangan maupun yang bertugas didalam Kantor Pemerintahan terkait pelaksanaan Aplikasi Tangerang Live. Sedangankan bagi masyarakat sebagai pengguna inovasi dapat memberikan jaminan bahwa pelayanan publik menjadi lebih responsif, artinya penyelenggaraan pelayanan publik didasarkan pada kebutuhan nyata masyarakat pengguna layanan sehingga terdapat kesesuaian antara pelayanan yang diberikan dengan kebutuhan masyarakat. Disamping itu memberikan jaminan transparansi bagi masyarakat, artinya masyarakat bisa mengetahui dengan mudah aspek-aspek pelayanan baik mengenai jenis, prosedur, waktu, biaya dan cara pelayanannya. Dan lebih akuntabel artinya pelayanan publik yang diberikan dapat dipertanggung jawabkan kepada masyarakat selaku pengguna layanan. Selain itu juga dapat memberikan kemudahan kepada masyarakat untuk mengakses informasi pelayanan dan sekaligus melakukan kontrol terhadap penyelenggaraan pelayanan, karena masyarakat dilibatkan secara langsung dalam proses pelayanan. Oleh sebeb itu inovasi pelayanan publik yang berbasis Apliksi Tangerang Live ini sangat cocok seiring dengan perkembangan teknologi informasi yang sedang berkembang dalam kehidupan masyarakat luas.

Meskipun begitu tetap ada indikator yang menurut hemat peneliti masih lemah yaitu terdapat pada observability atau kemudahan diamati. Dalam hal ini terjadi pada upaya sosialisasi yang dilakukan oleh Pemerintah Kota Tangerang masih belum optimal. Belum semua masyarakat Kota Tangerang mengetahui akan adanya Aplikasi Tangerang Live. Hal ini dapat dilihat dari jumlah downloader setelah dilaunchingnya Aplikasi ini yang baru mencapai angka 10000 downloader dari total 2.093.707 penduduk Kota Tangerang. Untuk itu diharapkan Dinas Komunikasi dan Informatika Kota Tangerang untuk terus aktif dalam menjalankan program sosialisasi tersebut agar semakin banyak menarik perhatian audience, dengan menampilkan media informasi Aplikasi Tangerang Live sehingga semakin banyak masyarakat Kota Tangerang yang mengetahui dan memanfaatkan layanan-layanan yang tersedia didalam aplikasi Tangerang Live yang dapat memudahkan masyarakat dalam hal pelayanan publik yang disediakan oleh Pemerintah Kota Tangerang.

Faktor Pendukung dan Penghambat Pelaksanaan Inovasi Tangerang Live.

Faktor pendukung

Komitmen Pemerintah Dalam hal ini bentuk komitmen Pemerintah dalam mendukung pelaksanaan Aplikasi Tangerang Live yaitu melalui kebijakan Pemerintah yang diatur dalam Peraturan Walikota Tangerang No 3 Tahun 2016, tentang pembentukan 
organisasi dan tata kerja unit pelaksana teknis command center pada Dinas Komunikasi dan Informatika.

Sarana dan Prasarana Pendukung. Dalam hal ini faktor yang mendukung pelaksanaan Aplikasi Tangerag Live yaitu adanya sarana dan prasarana yang dimiliki. Menurut hasil observasi dan wawaancara bahwa, untuk mendukung pelaksanaan Aplikasi Tangerang Live terdapat ruang control atau ruang kendali Aplikasi Tangerang Live lengkap dengan satu monitor atau layar besar serta 10 server berikut dengan operator masing-masing.

Kompetisi Inovasi Adanya dorongan dari pemerintah melalui Kementrian PAN-RB yang menyelenggarakan kompetisi inovasi pelayanan publik.tentu saja hal mendorong setiap instansi untuk bersaing meningkatkan pelayanan melalui berbagai inovasi yang memberikan kemudahan dan manfaat bagi masyarakat. Hal ini tentu saja akan berdampak pada kredibilitas Pemerintah Kota Tangerang sebagai instansi yang berusaha untuk memberikan pelayanan publik dengan baik.

Faktor Penghambat Pelaksanaan Inovasi Aplikasi Tagerang Live

Sumber daya manusia. Dalam hal ini keterampilan pengguna atau masyarakat tentu saja mempegaruhi cepat lambatnya penggunaan sebuah inovasi. Menurut hasil obervasi dan wawancara bahwa, tidak semua masyarakat faham terhadap teknologi informasi sehingga tidak semua masyarakat dapat menggunakan Aplikasi Tangerang Live.

Kurangnya Sosialisasi Seberapa besar upaya yang dilakukan dalam kegiatan sosialisasi sangat mempengaruhi pelaksanaan sebuah inovasi. Menurut hasil observasi dilapangan masih banyak masyarakat yang belum tahu informasi tetang Inovasi Aplikasi Tangerang Live. Sehingga perlu adanya soialisasi secara mendalam agar masyarakat benar-benar mengetahu cara menggunakan Aplikasi Tangeraang Live.

Belum bisa diakses oleh smatphone yang berbasis IOS. Saat ini Aplikasi Tangerang Live belum bisa diakses atau diinstal melalui smartphone yang berbasis IOS hanya bisa diakses melalui smartphone yang berbasis android.

\section{Saran}

Bagi Pemerintah Kota Tangerang Untuk melakukan sosialisasi kepada masyarakat tentang penggunaan aplikasi tangerang live. Karena banyak masyarakat yang masih belum tau cara penggunaan aplikasi tangerang live

Bagi Admin aplikasi tangerang live untuk mengintegrasikan aplikasi ke smartphone yang berbasis IOS atau Iphone agar bisa diakses oleh masyarakat pengguna Iphone. Sehingga penggunaan aplikasi oleh masyarakat menjadi ebih maksimal.

\section{DAFTAR PUSTAKA}

Everett M. Rogers (1983)., Diffusion Of Innovations, the free fress, New York

Gumilar Gugun, Direktur Eksekutif Institute Democracy and Education (IDE), 2015, Kualitas Pelayanan Publik Dianggap Masih Rendah, dalam (http://www.ti.or.id/index.php/news/2016/01/04/2015kualitas-pelayanan-publik-dianggap-masih-rendah)

Jogiyanto HM. (2000), Analisis dan Desain Sistem Informasi : Pendekatan terstruktur teori dan praktis aplikasi bisnis. Andi. Yogyakarta

Pasolong, Harbani (2010), Teori Administrasi Publik, Alfabeta, Bandung

Prahasta, Eddy (2001), Konsep - Konsep Dasar Sistem Informasi Geografi, Informatika, Bandung.

Prianto, Agus (2006), Menakar Kualitas Pelayanan Publik. Malang: In-Trans http://www.kabarbanten.com/site/index/tangerang/selain-pertanian-dansosialombudsman-minta-pendidikan-ditingkatkan2486.html

Poerwanto Sumo Bambang, (2016), Kepala Perwakilan Ombudsman RI Provinsi Banten dalam acara Rapat Evaluasi Pembangunan yang dilaksanakan oleh Pemerintah Kota (Pemkot) Tangerang di Ruang Rapat Akhlakual Karimah Puspem Kota Tangerang.

Ramli, (2013), Ilmu Administrasi Negara, FISIP; Lab. Otoda, Univ. Tribhuwana Tunggadewi, Malang.

Rogers, Everett M. (1995) .Diffusion ofInnovations. London: The Tree Press.

Rangkuti M, (2017). Ombudsman Minta Pemkot Tangerang Benahi Pelayanan Publik, dalam https://lensatangerang.com/2017/02/08/ombudsmanminta-pemkot-tangerang-benahi-pelayanan-publik/. Diakses September 2017.

Suwarno, Yogi. (2008). Inovasi di Sektor Publik. Jakarta. STIA -LAN Press

Sugiyono. 2012. Metode Penelitian Administrasi, Dilengkapi dengan metode R\&D.Bandung: Alfabeta.

Sutrisno, Edy ( 2010), Manajemen Sumber Daya Manusia. Jakarta: Kencana. Prenada Media Group

Wenny Aztriyani Pahusa, Retnowati WD Tuti. (2017), IMC 2016 Proceedngs, 2017-jurnal. Umj.ac.id

Wahyono, Teguh (2004), Sistem Informasi (Konsep Dasar, Analisis, Desain dan Implementasi. Graha Ilmu, Yogyakarta.

Wijayanti, Irine Diana Sari. (2008), 
Manajemen. Editor: Ari Setiawan. Yogyakarta: Mitra Cendikia.

Widodo Joko, 2001. Etika Birokrasi dalam Pelayanan Publik, 131, CV Citra Malang.

(http://tangerangkota.go.id/peresmian-

tangerang-live-room-oleh-walikota-tangerang-harief-r-wismanyah. akses 14 September 2017 ). 